\title{
Aplikasi Sistem Pendukung Keputusan Guru Terbaik Berdasarkan Kinerja dengan Metode Analytical Hierarchy Process (AHP)
}

\author{
Aulia Paramita1,*, Fanisya Alva Mustika², Naely Farkhatin ${ }^{3}$ \\ 1,2,3 Teknik Informatika, Universitas Indraprasta PGRI \\ (corresponding author) aulia.pps@gmail.com ${ }^{1, *}$,funny.alva@gmail.com ${ }^{2}$,naely_farkhatin@yahoo.com ${ }^{3}$
}

\begin{abstract}
Teacher is professional educator that has responsible, function, and important role in educating the nation. In order for the functions and duties inherent in the functional position of teacher conducted in accordance with the applicable rules, it is necessary to assess the performance of teacher can guarantee a quality learning process. In determining performance of teacher could encourage an increase education quality and increase motivation and professionalism of teacher in performing their tasks. The headmaster made 15 criteria to determine the best teacher, namely: attendance, discipline rules, responsibility and productivity, social interaction, motivation and self-development, innovative, responsive and initiative, flexibility in other tasks, communication, teamwork, honesty, friendly and polite, aesthetic dress, effective in using the gadget, cleanliness and tidiness class. In order to determine teacher performance, a decision can be done using the Analytical Hierarchy Process (AHP). A decision making is expected to choose an effective teacher performance. Determination of teacher's performance is further processed by the criterium Decision Plus (CDP). The results of this study are the order of 4 of the best teachers at Yayasan Lentera Insan.
\end{abstract}

Keywords : Analytical Hierarchy Process, Teacher, Performance, Decision Support System, Criterium Decision Plus

Intisari- Guru adalah pendidik profesional yang mempunyai tugas, fungsi dan peran penting dalam mencerdaskan kehidupan bangsa. Agar fungsi dan tugas yang melekat pada jabatan fungsional guru dilaksanakan sesuai dengan aturan yang berlaku, maka diperlukan Penilaian Kinerja Guru yang menjamin terjadinya proses pembelajaran yang berkualitas di semua jenjang pendidikan. Menentukan kinerja guru dapat mendorong peningkatan mutu pendidikan dan meningkatkan motivasi dan profesionalisme guru dalam pelaksanaan tugas, agar dapat mewujudkan kinerja guru tersebut, maka kepala sekolah membuat 15 kriteria untuk menentukan guru terbaik. Kriteria penilaian tersebut antara lain : kehadiran, kedisiplinan aturan, tanggung jawab dan produktivitas, interaksi sosial, motivasi dan pengembangan diri, inovatif, responsif dan inisiatif, fleksibilitas dalam tugas lain, komunikasi, teamwork, kejujuran, ramah dan santun, estetika berpakaian, efektif dalam menggunakan gadget, kebersihan dan kerapihan kelas. Untuk menentukan kinerja guru tersebut, maka salah satu pengambilan keputusan yang dapat dilakukan dengan menggunakan Analytical Hierarchy Process(AHP). Dengan pengambilan keputusan tersebut diharapkan mampu memilih kinerja guru dengan efektif. Kriteria Penentuan kinerja guru tersebut selanjutnya diolah dengan Criterium Decision Plus(CDP). Hasil dari penelitian ini adalah urutan 4 guru terbaik pada Yayasan Lentera Insan.

Kata Kunci-Analytical Hierarchy Process, Guru, Kinerja, Sistem Pendukung Keputusan, Criterium Decision Plus

\section{PENDAHULUAN}

Guru adalah pendidik profesional yang mempunyai tugas, fungsi, dan peran penting dalam mencerdaskan kehidupan bangsa. Guru yang profesional diharapkan mampu berpartisipasi dalam pembangunan nasional untuk mewujudkan insan Indonesia yang bertakwa kepada Tuhan YME, unggul dalam ilmu pengetahuan dan teknologi, memiliki jiwa estetis, etis, berbudi pekerti luhur dan berkepribadian. Oleh sebab itu, profesi guru perlu dikembangkan secara terus menerus dan proporsional menurut jabatan fungsional guru. Selain itu, agar fungsi dan tugas yang melekat pada jabatan fungsional guru dilaksanakan sesuai dengan aturan yang berlaku, maka diperlukan Penilaian Kinerja Guru (PK GURU) yang menjamin terjadinya proses pembelajaran yang berkualitas di semua jenjang pendidikan.

Salah satu metode komputasi yang cukup berkembang saat ini adalah metode sistem pengambilan keputusan (Decision Support System). Dalam teknologi informasi, sistem pengambilan keputusan merupakan cabang ilmu yang letaknya diantara sistem informasi dan sistem cerdas. Sistem pengambilan keputusan juga membutuhkan teknologi informasi, hal ini dikarenakan adanya era globalisasi, yang menuntut sebuah sekolah untuk bergerak cepat dalam mengambil suatu keputusan dan tindakan. Dengan mengacu kepada solusi yang diberikan oleh metode AHP (Analytical 
Hierarcy Process) dalam membantu membuat keputusan, seorang decision maker dapat mengambil keputusan tentang pemilihan guru terbaik sesuai dengan kinerjanya secara objektif berdasarkan multi kriteria yang ditetapkan.

Menetapkan kinerja guru dapat mendorong peningkatan mutu pendidikan dan meningkatkan motivasi serta profesionalisme guru dalam pelaksanaan tugas, agar dapat diwujudkan kinerja guru tersebut, maka kepala sekolah membuat kriteria atau persyaratan untuk menentukan kinerja guru dan memilih dan memberikan penghargaan guru terbaik sesuai dengan kinerjanya. Agar semua guru yang ada di Yayasan Lentera Insan Depok termotivasi menjadi guru yang professional. Tim peneliti ingin membantu membuat "Aplikasi Sistem Pendukung Keputusan Guru Terbaik Berdasarkan Kinerja dengan Metode Analytical Hierarchy Process (AHP)”.

\section{TINJAUAN PUSTAKA}

\section{A. Penilaian Guru}

Penilaian adalah mengambil suatu keputusan terhadap sesuatu dengan ukuran baik buruk [1]. Penilaian bersifat kualitatif. Untuk dapat melakukan penilaian perlu melakukan pengukuran terlebih dahulu, sedangkan pengukuran tidak akan mempunyai makna yang berarti tanpa dilakukan penilaian. Ref [2] menunjukkan bahwa penilaian berarti menilai sesuatu. Sedangkan menilai itu mengandung arti : mengambil keputusan terhadap sesuatu dengan mendasarkan diri atau berpegang pada ukuran baik atau buruk, sehat atau sakit, pandai atau bodoh dan sebagainya. Jadi penilaian itu sifatnya adalah kualitatif. Selanjutnya, referensi [3] mendefinisikan penilaian sebagai semua aktifitas yang dilakukan oleh guru dan siswa untuk menilai diri mereka sendiri, yang memberikan informasi untuk digunakan sebagai umpan balik untuk memodifikasi aktivitas belajar dan mengajar. Sedangkan referensi [4] menunjukkan bahwa, penilaian guru adalah penilaian yang dilakukan terhadap setiap butir kegiatan tugas utama guru dalam rangka pembinaan karir, kepangkatan, dan jabatannya. Jadi dapat disimpulkan penilaian merupakan suatu proses memberikan atau menentukan nilai yang bersifat kualitatif terhadap hasil tertentu berdasarkan suatu kriteria tertentu.

\section{B. Kinerja}

Kinerja adalah hasil atau tingkat keberhasilan seseorang secara keseluruhan selama periode tertentu dalam melaksanakan tugas dibandingkan dengan berbagai kemungkinan, seperti standar hasil kerja, target atau sasaran atau kriteria yang telah ditentukan terlebih dahulu telah disepakati bersama [5]. Performance atau kinerja merupakan hasil atau keluaran dari suatu proses [6]. Sedangkan referensi [7] menyatakan bahwa kinerja pada dasarnya adalah apa yang dilakukan atau tidak dilakukan pegawai. Manajemen kinerja adalah keseluruhan kegiatan yang dilakukan untuk meningkatkan kinerja perusahaan atau organisasi, termasuk kinerja masing-masing individu dan kelompok kerja di perusahaan tersebut.

Berdasarkan pendapat beberapa ahli tersebut, dapat disimpulkan bahwa penilaian prestasi kerja (kinerja) adalah penilaian yang dilakukan secara sistematis untuk mengetahui hasil pekerjaan karyawan dan kinerja organisasi. Disamping itu, juga untuk menentukan pelatihan kerja secara tepat, memberikan tanggapan yang lebih baik di masa mendatang dan sebagai dasar untuk menentukan kebijakan dalam hal promosi jabatan dan penentuan imbalan.

Tujuan dari penilaian prestasi kerja (kinerja) adalah untuk memperbaiki atau meningkatkan kinerja organisasi dari SDM organisasi. Secara spesifik, tujuan dari evaluasi kinerja adalah[8] :

1) Meningkatkan saling pengertian antara karyawan tentang persyaratan kinerja.

2) Mencatat dan mengakui hasil kerja seseorang karyawan, sehingga mereka termotivasi untuk berbuat yang lebih baik, atau sekurang-kurangnya berprestasi sama dengan prestasi yang terdahulu.

3) Memberikan peluang kepada karyawan untuk mendiskusikan keinginan dan aspirasinya dan meningkatkan kepedulian terhadap karir atau terhadap pekerjaan yang diembannya sekarang.

4) Mendefinisikan atau merumuskan kembali sasaran masa depan, sehingga karyawan termotivasi untuk berprestasi sesuai dengan potensinya.

5) Memeriksa rencana pelaksanaan dan pengembangan yang sesuai dengan kebutuhan pelatihan, khusus rencana diklat, dan kemudian menyetujui rencana itu jika tidak ada hal-hal yang perlu diubah.

\section{Analytical Hierarchy Process}

Metode AHP merupakan salah satu model untuk pengambilan keputusan yang dapat membantu kerangka berfikir manusia. Metode ini mula-mula dikembangkan oleh Thomas L. Saaty pada tahun 70-an. Dasar berpikir metode AHP adalah proses membentuk skor secara numerik untuk menyusun rangking setiap alternatif keputusan berbasis pada bagaimana sebaiknya alternatif itu dicocokkan dengan kriteria pembuat keputusan[9]. AHP memungkinkan untuk melihat elemen-elemen permasalahan secara terpisah-pisah. Satu elemen kemudian dibandingkan dengan lainnya berdasarkan kriteria tunggal yang merupakan proses keputusan dari perbandingan berpasangan, serta membantu penyusunan permasalahan, mendorong melakukan pertimbangan/penilaian, dan mengumpulkan atau menggabungkan semua pertimbangan kedalam alternatif-alternatif yang diprioritaskan dari yang paling baik sampai yang paling buruk. 
Konsep metode AHP adalah merubah nilai-nilai kualitatif menjadi nilai kuantitatif. Sehingga keputusan-keputusan yang diambil bisa lebih obyektif. Ada beberapa prinsip yang harus dipahami dalam menyelesaikan persoalan dengan AHP, diantaranya adalah: decomposition, comparative judgement, synthesis of priority dan logical consistency.

1) Decomposition

Setelah persoalan didefinisikan, maka perlu dilakukan decomposition yaitu memecah persoalan yang utuh menjadi unsur-unsurnya. Jika ingin mendapatkan hasil yang akurat, pemecahan juga dilakukan terhadap unsurunsurnya sampai tidak mungkin dilakukan pemecahan lebih lanjut, sehingga didapatkan beberapa tingkatan dari persoalan tadi. Karena alasan ini, maka proses analisis ini dinamakan hirarki (hierarchy). Ada dua jenis hirarki yaitu lengkap dan tak lengkap. Dalam hirarki lengkap, semua elemen pada suatu tingkat memiliki semua elemen yang ada pada tingkat berikutnya. Jika tidak, dinamakan hirarki tak lengkap.

2) Comparative Judgement

Prinsip ini berarti membuat penilaian tentang kepentingan relatif dua elemen pada suatu tingkat tertentu dalam kaitannya dengan tingkat di atasnya. Penilaian ini merupakan inti dari AHP, karena ia akan berpengaruh terhadap prioritas elemen- elemen.

3) Synthesis of Priority

Dari setiap pairwise comparison kemudian dicari eigen vectornya untuk mendapatkan local priority. Karena matriks pairwise comparison terdapat pada setiap tingkat, maka untuk mendapatkan global priority harus dilakukan sintesa diantara local priority. Prosedur melakukan sintesis berbeda menurut bentuk hirarki. Pengurutan elemenelemen menurut kepentingan relatif melalui prosedur sintesa dinamakan priority setting.

4) Logical Consistency

Konsistensi memiliki dua makna. Pertama adalah bahwa objek-objek yang serupa dapat dikelompokkan sesuai dengan keseragaman. Kedua adalah menyangkut tingkat hubungan antara objek-objek yang didasarkan pada kriteria tertentu.

\section{Metodologi Penelitian}

\section{A. Metode Penelitian}

Penelitian yang dilakukan merupakan penelitian deskriptif kuantitatif. Penelitian deskriptif adalah penilaian yang dilakukan untuk mengetahui nilai variable mandiri tanpa membuat perbandingan atau membangun hubungan dengan variable yang lain. Penelitian ini ditujukan untuk memberikan gambaran atau uraian atas suatu keadaan sejelas mungkin tanpa ada perlakuan terhadap objek yang akan diteliti.

Penelitian kuantitatif dimana peneliti melakukan pengujian dari hipotesa dengan teknik-teknik statistik. Data statistik tersebut didapatkan dari kuesioner dengan menggunakan metode pendekatan Analytical Hierarchy Process (AHP) dan kemudian diuji dengan menggunakan tool Criterium Decision Plus (CDP).

\section{B. Populasi dan Sampel}

Populasi pada penelitian ini adalah seluruh guru Yayasan Lentera Insan Sedangkan sampel data yang digunakan pada penelitian ini adalah seluruh data populasi dari penelitian tersebut.

\section{Metode Pengumpulan Data}

Proses pengumpulan data pada penelitian ini dilakukan dengan 2 cara yaitu:

1) Pengumpulan data primer, dengan melakukan survei sesuai dengan kebutuhan dan kondisi yang ada kemudian mengumpulkan data dari responden ahli, teknik yang digunakan adalah kuesioner dan wawancara.

2) Pengumpulan data sekunder, dikumpulkan dengan mengamati data, membaca dan mempelajari dan mengutip dari buku literatur.

\section{Instrumen Penelitian}

Penelitian ini menggunakan kuesioner sebagai instrumen untuk memperoleh data dalam proses penentuan guru terbaik. Pengumpulan data dilakukan dengan melalui beberapa tahap. Pada tahap awal dilakukan wawancara kepada responden ahli untuk mendapatkan kriteria penentu guru terbaik. Wawancara juga dilakukan untuk mendapatkan kandidat guru terbaik.

Pada tahap selanjutnya adalah membuat kuesioner perbandingan berpasangan di antara elemen pada masingmasing level, data kuesioner diolah dengan pendekatan proses AHP, dengan menggunakan manipulasi matrik dan menggunakan tool CDP. 


\section{HASIL DAN PEMBAHASAN}

\section{A. Analisis Data}

Data yang digunakan dalam penelitian ini didapatkan dari SD Lentera Insan, yaitu data kriteria penilaian dan data guru yang dinilai. Kriteria penenentuan guru terbaik pada SD Lentera Insan dijabarkan dalam 15 kriteria penilaian.

1) Pembentukan Struktur Hirarki Penentuan Guru Terbaik

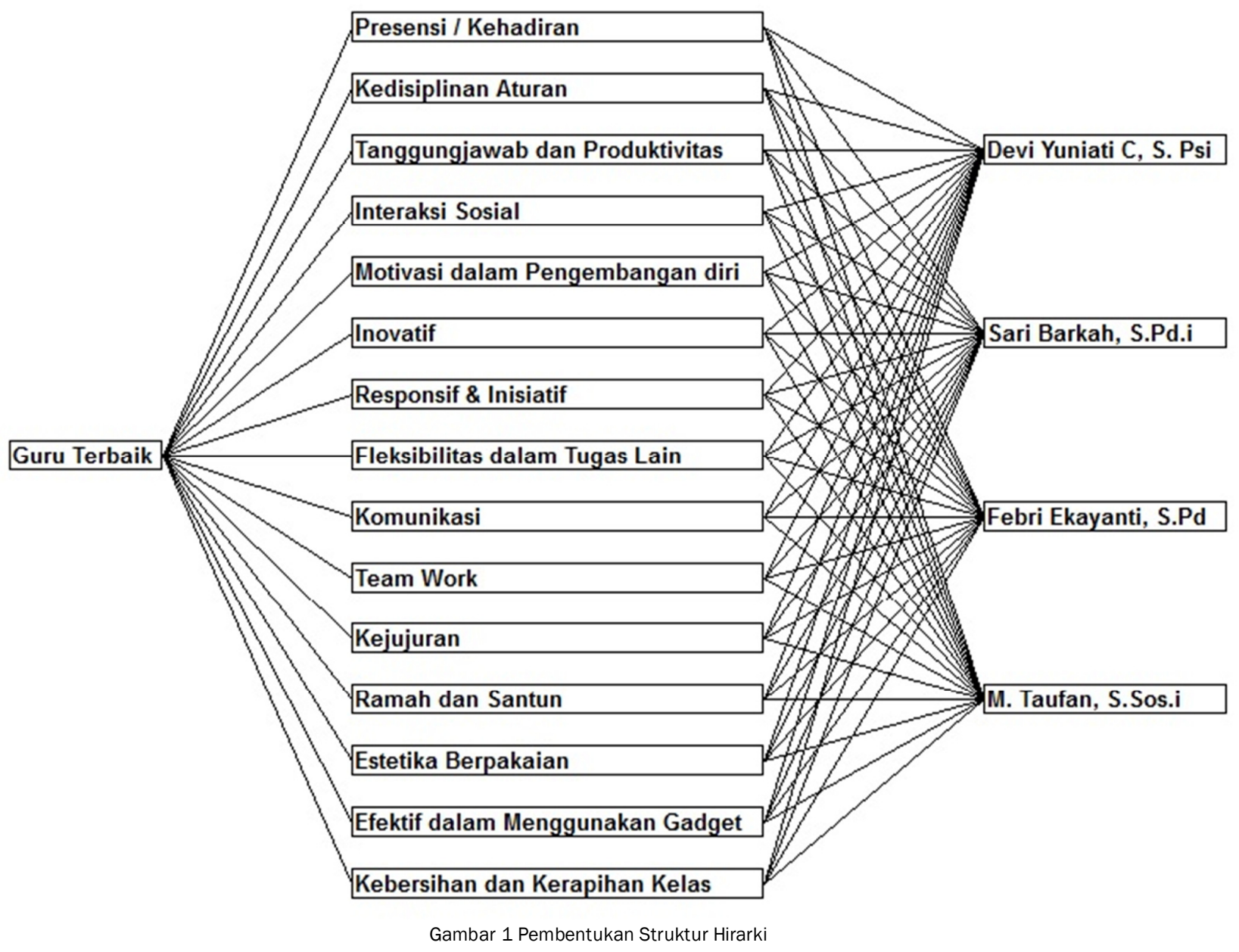

Keterangan :
a. Level Sasaran
: Sasaran dari keputusan yaitu penentuan Guru Berprestasi.
b. Level Kriteria
: Kriteria penilaian Guru Berprestasi.
c. Alternatif
: Guru yang dinilai berdasarkan masing-masing kriteria.

2) Skor Penilaian Tingkat Kepentingan

Skor penilaian tingkat kepentingan digunakan pada kuesioner dan aplikasi Criterium Decision Plus dalam membandingkan antar kriteria dan antar alternatif guru yang dinilai. Penilaian dimaksudkan untuk membandingkan nilai atau karakter pilihan berdasarkan tiap kriteria yang ada. Misalnya antara pilihan 1 dan pilihan 2, pada kriteria 1, lebih penting pilihan 1, selanjutnya antara pilihan 1 dan pilihan 3, lebih penting pilihan 3 dan seterusnya hingga semua pilihan akan dibandingkan satu-persatu (secara berpasangan). Hasil dari penilaian adalah nilai/bobot yang merupakan karakter dari masing-masing alternatif. Dari 15 kriteria akan dibandingkan antara satu kriteria dengan kriteria yang lain berdasarkan tingkat kepentingannya seperti dalam tabel penilaian tingkat kepentingan berikut ini. 
Tabel 1. Skor Penilaian Tingkat Kepentingan

\begin{tabular}{|c|l|}
\hline Nilai Skor & \multicolumn{1}{c|}{ Keterangan } \\
\hline 1 & Kriteria yang satu dengan yang lainnya sama penting \\
\hline 3 & $\begin{array}{l}\text { Kriteria yang satu sedikit lebih penting (agak kuat) dibanding } \\
\text { Kriteria lainnya. }\end{array}$ \\
\hline 5 & $\begin{array}{l}\text { Kriteria yang satu sifatnya lebih penting (lebih kuat pentingnya) } \\
\text { dibanding Kriteria lainnya }\end{array}$ \\
\hline 7 & Kriteria yang satu sangat penting dibanding Kriteria lainnya \\
\hline 9 & Kriteria yang satu ekstrim pentingnya dibanding Kriteria lainnya \\
\hline $2,4,6,8$ & Nilai tengah di antara dua nilai skor penilaian diatas \\
\hline
\end{tabular}

\section{B. Pengolahan Data AHP}

1) Penilaian Kriteria dan Alternatif

\section{a. Penilaian Kriteria}

Dalam pembobotan tingkat kepentingan atau penilaian perbandingan berpasangan ini berlaku hukum aksioma reciprocal, artinya apabila suatu elemen A dinilai lebih esensial (5) dibandingkan dengan elemen $B$, maka $B$ lebih esensial 1/5 dibandingakan dengan elemen A. Apabila elemen A sama pentingnya dengan B maka masing-masing bernilai $=1$. Dalam pengambilan data, misalnya dengan menggunakan kuisioner, prosedur perbandingan berganda dapat dilakukan dengan menggunakan kuisioner berupa matriks, yang disajikan dalam tabel 2.

Tabel 2 Matriks Penilaian Kriteria

\begin{tabular}{|c|c|c|c|c|c|c|c|c|c|c|c|c|c|c|c|}
\hline & K1 & K2 & K3 & K4 & K5 & K6 & K7 & K8 & K9 & K10 & K11 & K12 & K13 & K14 & K15 \\
\hline K1 & 1 & 1 & 1 & 1 & 1 & 1 & 1 & 1 & 1 & 0.2 & 0.1111 & 0.1429 & 0.1429 & 0.1111 & 0.1429 \\
\hline K2 & 1 & 1 & 1 & 7 & 1 & 1 & 1 & 1 & 1 & 1 & 1 & 1 & 1 & 1 & 1 \\
\hline K3 & 1 & 1 & 1 & 1 & 1 & 1 & 1 & 1 & 1 & 1 & 1 & 1 & 1 & 1 & 1 \\
\hline K4 & 1 & 0.1429 & 1 & 1 & 0.2 & 1 & 0.1429 & 1 & 1 & 1 & 0.1111 & 1 & 1 & 1 & 1 \\
\hline K5 & 1 & 1 & 1 & 5 & 1 & 1 & 0.1429 & 0.2 & 1 & 1 & 0.1111 & 1 & 1 & 1 & 5 \\
\hline K6 & 1 & 1 & 1 & 1 & 1 & 1 & 0.2 & 0.2 & 1 & 1 & 0.1111 & 1 & 1 & 1 & 1 \\
\hline K7 & 1 & 1 & 1 & 7 & 7 & 5 & 1 & 1 & 1 & 5 & 1 & 1 & 1 & 1 & 1 \\
\hline K8 & 1 & 1 & 1 & 1 & 5 & 5 & 1 & 1 & 1 & 1 & 0.1429 & 1 & 1 & 1 & 1 \\
\hline K9 & 1 & 1 & 1 & 1 & 1 & 1 & 1 & 1 & 1 & 1 & 1 & 1 & 1 & 1 & 1 \\
\hline K10 & 5 & 1 & 1 & 1 & 1 & 1 & 0.2 & 1 & 1 & 1 & 0.2000 & 1 & 1 & 1 & 1 \\
\hline K11 & 9 & 1 & 1 & 9 & 9 & 9 & 1 & 7 & 1 & 5 & 1 & 1 & 1 & 5 & 5 \\
\hline K12 & 7 & 1 & 1 & 1 & 1 & 1 & 1 & 1 & 1 & 1 & 1 & 1 & 1 & 1 & 1 \\
\hline K13 & 7 & 1 & 1 & 1 & 1 & 1 & 1 & 1 & 1 & 1 & 1 & 1 & 1 & 1 & 1 \\
\hline K14 & 9 & 1 & 1 & 1 & 1 & 1 & 1 & 1 & 1 & 1 & 0.2 & 1 & 1 & 1 & 1 \\
\hline K15 & 7 & 1 & 1 & 1 & 0.2 & 1 & 1 & 1 & 1 & 1 & 0.2 & 1 & 1 & 1 & 1 \\
\hline
\end{tabular}

b. Presensi/Kehadiran

Tabel 3 Matriks Penilaian Kriteria Presensi/Kehadiran
\begin{tabular}{|c|c|c|c|c|}
\hline K1 & G1 & G2 & G3 & G4 \\
\hline G1 & 1 & 9 & 9 & 9 \\
\hline G2 & 0.1111 & 1 & 0.1429 & 0.3333 \\
\hline G3 & 0.1111 & 7 & 1 & 7 \\
\hline G4 & 0.1111 & 3 & 0.1429 & 1 \\
\hline
\end{tabular}

Setelah dilakukan perbandingan antar 15 kriteria maka langkah selanjutnya adalah melakukan perbandingan antar alternatif. Dalam tabel 3, disajikan hasil perbandingan antara alternatif 1 (G1) sampai alternatif 4 (G4) untuk kriteria 1 yaitu Presensi/Kehadiran.

\section{Pengolahan Data dengan Criterium Decision Plus (CDP)}

Dalam pengolahan data AHP, adapun cara yang lebih mudah dalam melakukan pembobotan ini adalah dengan menggunakan bantuan program komputer seperti Criterium Decision Plus (CDP). Langkah pertama yaitu membuat hirarki penentuan guru terbaik dengan memasukkan 15 kriteria yang menjadi penentu guru terbaik. Dari pembuatan hirarki 
tersebut maka akan terbentuk kriteria penentu guru terbaik seperti yang ada pada gambar 2. Setelah terbentuk struktur hirarki penentuan guru terbaik, maka langkah berikutnya adalah melakukan perbandingan berpasangan antar kriteria yang dapat dilihat pada gambar 3 .

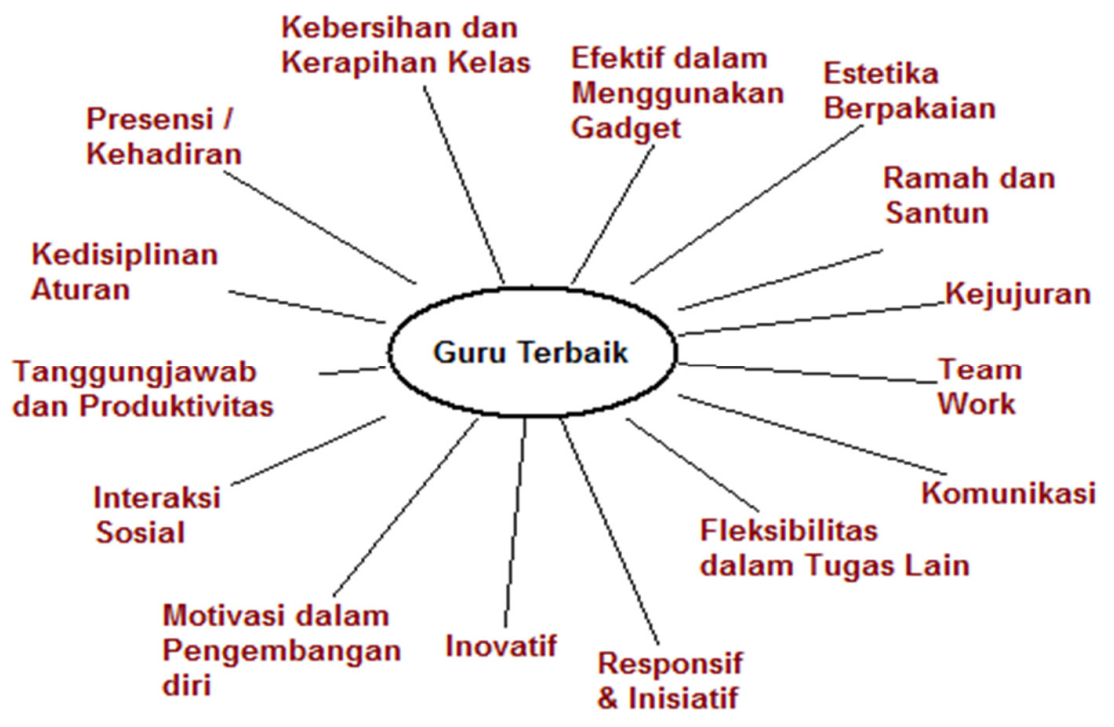

Gambar 2. Kriteria Penentu Guru Terbaik

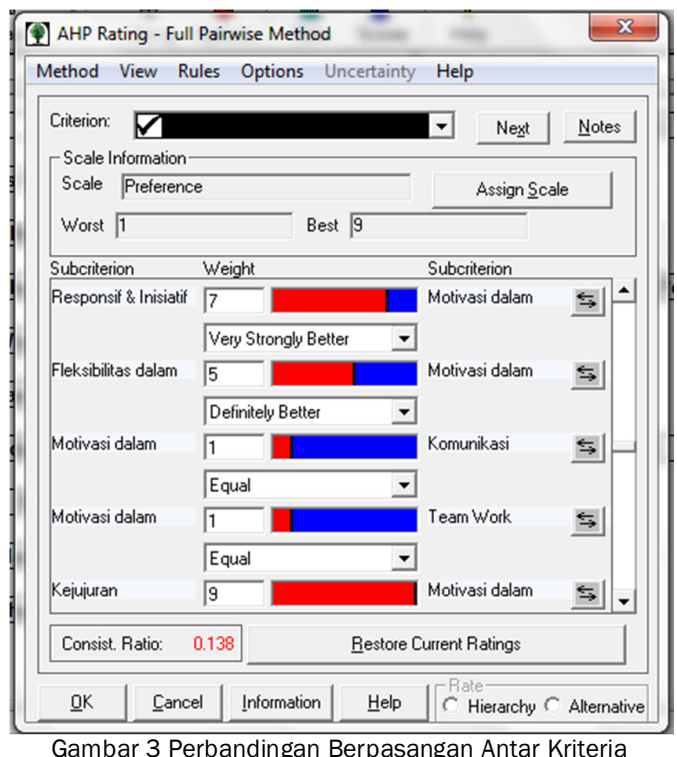

Langkah berikutnya adalah melakukan perbandingan antar alternatif. Dalam gambar 4 disajikan perbandingan antara alternatif 1 (Guru pertama) sampai alternatif 4 (Guru keempat) dengan kriteria tanggung jawab dan produktivitas. 


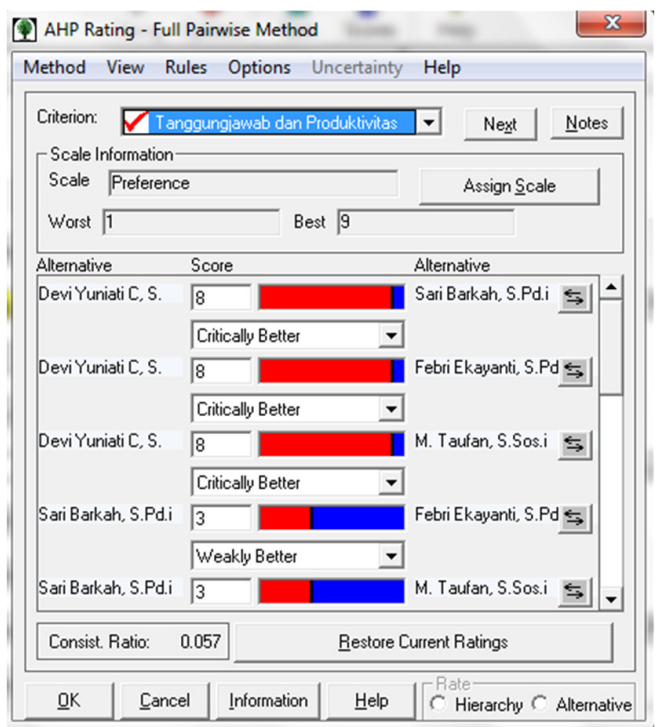

Gambar 4 Perbandingan Berpasangan Antar Alternatif pada Kriteria Tanggung Jawab dan Produktivitas

Setelah melakukan perbandingan antar kriteria dan antar alternative, langkah berikutnya adalah melihat hasil akhir penilaian seperti yang disajikan pada gambar 5 dan gambar 6 . Pada gambar 5 ditunjukkan hasil akhir dalam bentuk tabel, dimana dihasilkan Guru dengan nama Devi mendapat nilai akhir 0.323, Sari mendapat nilai akhir 0.235, Febri mendapat nilai akhir 0.220 dan M. Taufan mendapat ni;ai akhir 0.222. selain hasil masing-masing nilai setiap guru, didapatkan juga bobot nilai untuk masing-masing kriteria dan kriteria tertinggi adalah kejujuran. Pada gambar 6 hasil akhir ditunjukkan dalam bentuk grafik sesuai dengan nilai akhir masing-masing guru.

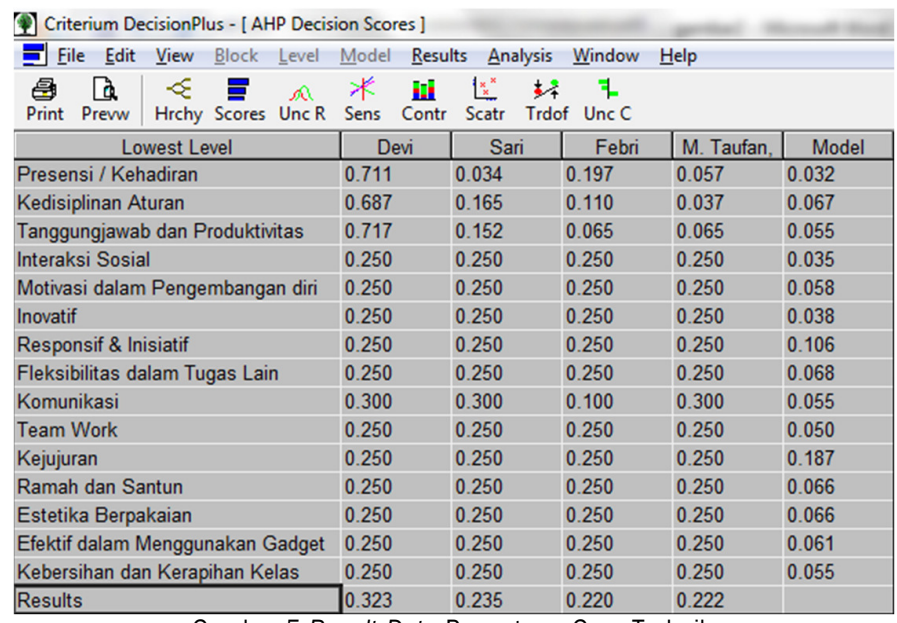

Gambar 5 Result Data Penentuan Guru Terbaik

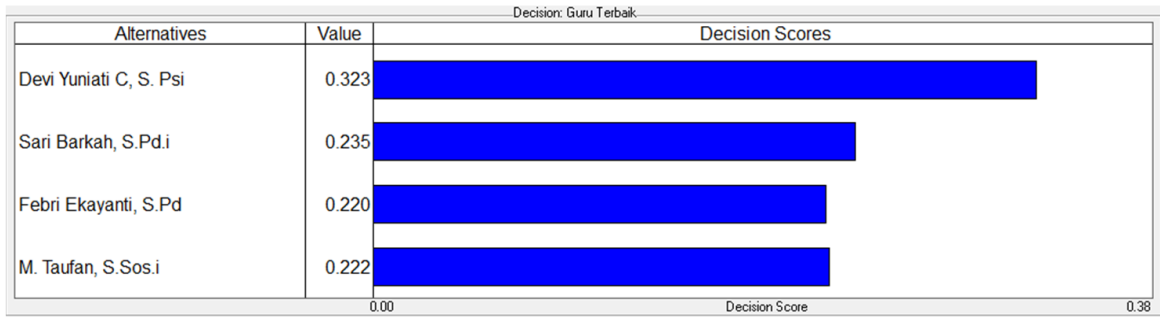

Gambar 6 Grafik Decision Scores Penentuan Guru Terbaik 
Berdasarkan hasil pengolahan data menggunakan tool Criterium Decision Plus di atas, didapatkan urutan guru terbaik pada Lentera Insan yaitu : Devi Yuniati C, S.Psi dengan value 0.323, diikuti dengan Sari Barkah, S.Pd.i dengan value 0.235, kemudian M. Taufan, S.Sos.i dengan value 0.222, dan Febri Ekayanti, S.Pd dengan value 0.220 .

\section{Aplikasi Penilaian Guru Terbaik}

Aplikasi penilaian guru terbaik dibuat dengan tools Netbeans dan MySQI. Apliksi ini digunakan sebagai alat bantu untuk kepala sekolah dalam menentukan guru terbaik berdasarkan kinerja setiap tahunnya. Aplikasi penilaian guru terbaik dibangun berdasarkan logika AHP dengan menggunakan bobot nilai kriteria yang sudah didapatkan dari hasil pengolahan data kuesioner.

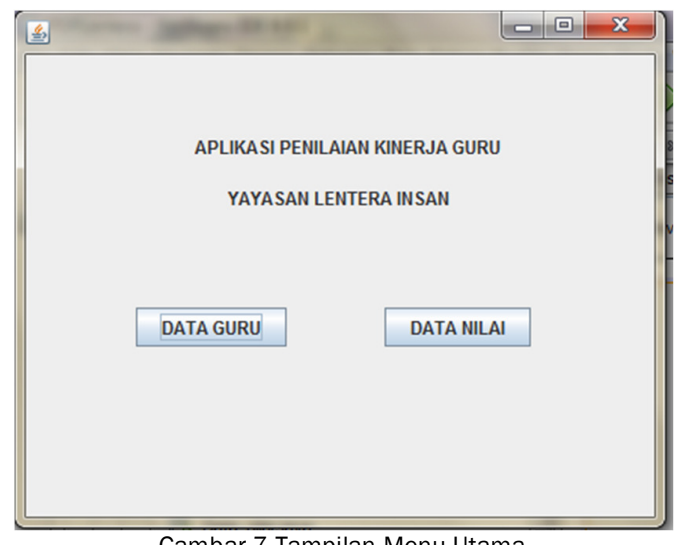

Gambar 7 Tampilan Menu Utama

Awal program akan menampilkan Menu Utama seperti pada gambar 7. Dalam tampilan ini Terdapat dua tombol yang masing-masing akan memanggil Form Data Guru dan Form Penilaian Guru.

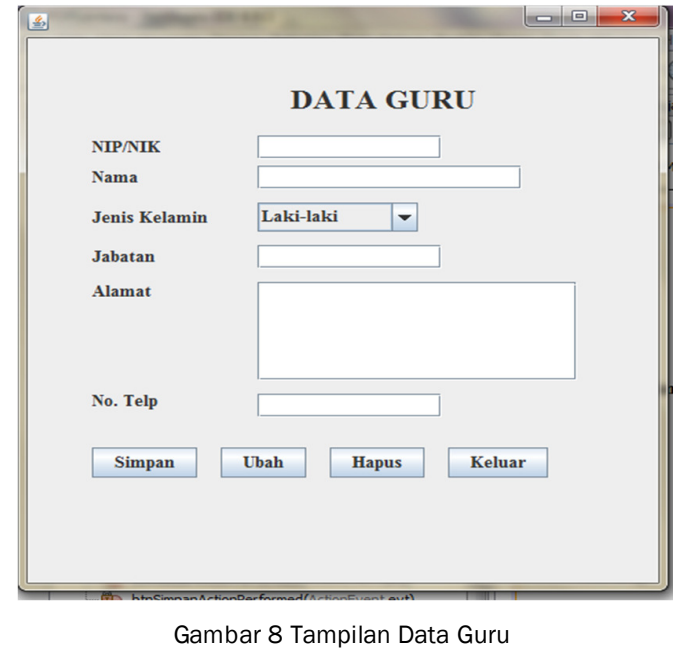

Dalam gambar 8 terdapat Tampilan Data Guru. Dalam tampilan ini akan dimasukkan inputan berupa data guru yang mengajar di yayasan Lentera Insan yang nantinya akan dinilai setiap tahunnya. Terdapat empat tombol yang masingmasing berfungsi untuk mengolah data guru. 


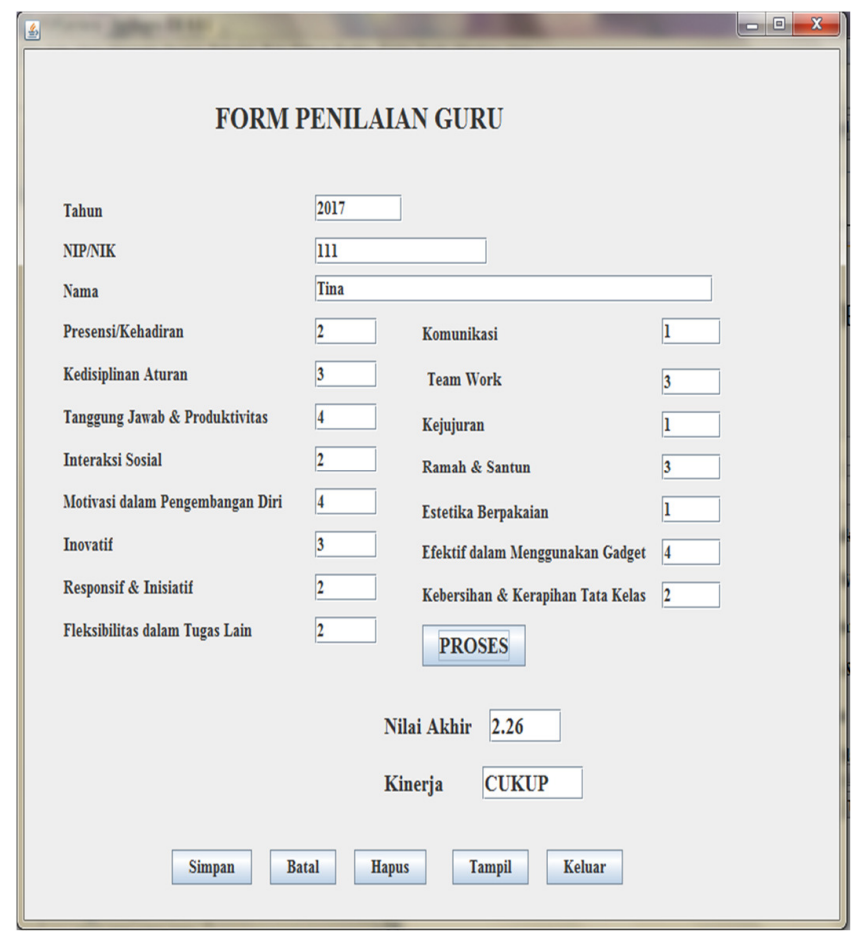

Gambar 9 Tampilan Form Penilaian Guru

Dalam gambar 9 terdapat menu Form Penilaian Guru yaitu form untuk memasukkan nilai masing-masing kriteria untuk setiap guru yang sudah ditetapkan dalam penilaian guru terbaik berdasarkan kinerja setiap tahunnya. Bobot penilaian yang dimasukkan untuk setiap kriteria berkisar antara 1 - 4 sesuai standard yang telah ditetapkan oleh Yayasan Lentera Insan. Nilai akhir akan dihasilkan dengan cara mengalikan bobot masing-masing kriteria yang sudah diinput untuk setiap guru dengan bobot masing-masing kriteria yang dihasilkan dari pengolahan data AHP.

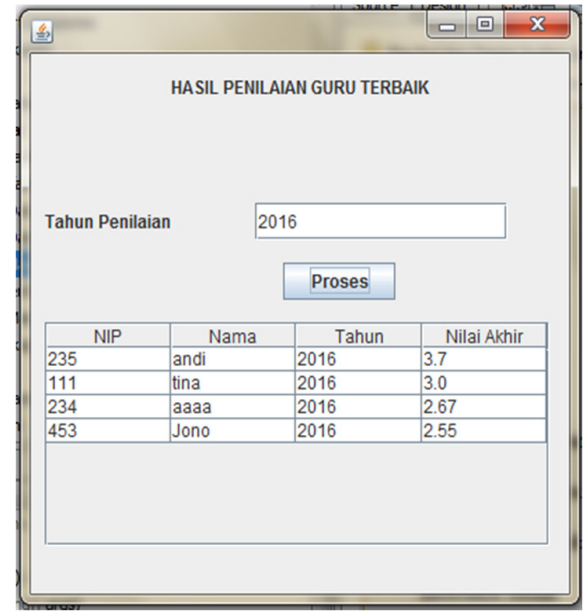

Gambar 10 Tampilan Hasil Penilaian Guru

Dalam gambar 10 disajikan Tampilan Hasil Penilaian Guru. Hasil ini akan diperoleh jika sebelumnya data guru sudah diinput serta dinilai. Hasil penilaian guru dapat ditampilkan berdasarkan tahun dan akan ditampilkan berdasarkan nilai tertinggi yang menandakan bahwa guru tersebut merupakan guru terbaik. 


\section{KESIMPULAN}

Berdasarkan pembahasan hasil penelitian yang telah dibahas di bab sebelumnya, maka dalam penelitian ini dapat diambil simpulan sebagai berikut:

1) Penentuan guru terbaik pada Yayasan Lentera Insan dapat dianalisis dengan pendekatan AHP (Analytical Hierachy Process).

2) Penentuan guru terbaik pada Yayasan Lentera Insan dengan pendekatan AHP (Analytical Hierachy Process) menggunakan 15 kriteria dalam menentukan keputusan.

3) Aplikasi penilaian guru terbaik dapat dibangun dengan data yang dihasilkan dari pengolahan menggunakan pendekatan AHP.

\section{REFERENSI}

[1] Arikunto, Suharsimi. Dasar-Dasar Evaluasi Pendidikan. Jakarta: Bumi Aksara. 2009

[2] Sudijono, Anas. Pengantar Evalusi Pendidikan. Jakarta: PT RajaGrafindo Persada. 2006.

[3] Rasyid, Harun \& Mansur. Penilaian Hasil Belajar. Bandung: CV. Wacana Prima. 2007.

[4] Peraturan Menteri Pemberdayaan Aparatur Negara dan Reformasi Birokrasi Nomor 16 Tahun 2009 tentang Jabatan Fungsional Guru dan Angka Kreditnya.

[5] Rivai, Vethzal \& Basri. Peformance Appraisal: Sistem yang tepat untuk Menilai Kinerja Karyawan dan Meningkatkan Daya Saing Perusahan. Jakarta: PT. RajaGrafindo Persada. 2005.

[6] Nurlaila. Manajemen Sumber Daya Manusia I. Penerbit LepKhair. 2010.

[7] Mathis, R.L. \& J.H. Jackson. Human Resource Management: Manajemen Sumber Daya Manusia. Terjemahan Dian Angelia. Jakarta: Salemba Empat. 2006.

[8] Mangkunegara, A.A. Anwar Prabu. Evaluasi Kinerja. Bandung : Refika Aditama. 2005.

[9] Supriyono, Wisnu Arya Wardhana, Sudaryo, "Sistem Pemilihan Pejabat Struktural dengan Metode AHP", ISSN 1978-0176, hal. 311-322. Nov. 2007 